Gut, 1961, 2, 141

\title{
Iron deficiency after partial gastrectomy
}

\author{
J. R. НОВBS
}

From the Central Middlesex Hospital, London ${ }^{1}$

SYNOPSIS Iron-deficiency anaemia will develop in half the males and nearly all females after partial gastrectomy, and in addition to causing the anaemia the sideropenia may cause any general symptoms such as lassitude, failure to maintain weight, or dumping symptoms.

The variable response to treatment is due to the fact that ferrous iron is not adequately released from coated tablets taken after meals and rapidly emptied from the gastric remnant. Treatment with chelated iron is more reliable, and one tablet taken on lying down each night is adequate in the treatment of mild anaemia and for its prevention in women during the reproductive life.

\section{PART I: AETIOLOGY}

After partial gastrectomy iron deficiency is common and notoriously difficult to treat orally (Owren, 1952; Goldeck and Gadermann, 1954; Wallensten, 1954). The object of this study was to clarify the relative importance of the many suggested causes with a view to clinical management.

\section{MATERIAL}

All patients of this hospital who underwent partial gastrectomy for a benign ulcer in 1954 and 1955 were followed up with the results shown in Table I.

\section{TABLE I}

RESULTS OF FOLLOW-UP OF 347 PATIENTS SUBMITTED TO PARTIAL GASTRECTOMY FOR BENIGN ULCERS DURING 1954 AND 1955

\begin{tabular}{|c|c|c|c|c|}
\hline \multirow{2}{*}{$\begin{array}{l}\text { Sex } \\
\text { Type of aperation }\end{array}$} & \multicolumn{2}{|l|}{ Male } & \multicolumn{2}{|l|}{ Female } \\
\hline & Billroth I & Polya & Billroth I & Polya \\
\hline Dead & 6 & 12 & 1 & 0 \\
\hline Untraced & 17 & 38 & 3 & 4 \\
\hline Did not attend & 0 & 1 & 1 & 1 \\
\hline \multicolumn{5}{|l|}{ Excluded because of a } \\
\hline the haematology & 2 & 2 & 0 & 0 \\
\hline Seen in person & 56 & 124 & 18 & 26 \\
\hline Seen at local hospital & 7 & 5 & 3 & 3 \\
\hline \multirow[t]{2}{*}{ Totals seen } & 63 & 129 & 21 & 29 \\
\hline & \multicolumn{4}{|c|}{242} \\
\hline
\end{tabular}

The patients were evenly distributed with regard to age, had had similar pre-operative selection and care throughout, were all within three to five years

'Present address: Department of Chemical Pathology, Westminster Hospital, London, S.W.1 of operation, and were well documented, thus being suitable subjects for statistical analysis.

\section{METHODS}

After an interview to elicit details of post-operative diet (from which the average daily intake of iron in food was calculated, using Scientific Tables, J. R. Geigy, S.A., Basle, 1956) consumption of alkali and aspirin, and any blood loss or treatment, patients were weighed and venepuncture performed.

Haemoglobin was determined (Gibson and Harrison, 1945 ) in duplicate, reducing the technical error to $\pm 0.5 \%$. The $6 \%$ to $11 \%$ variation (McCarthy and Van Slyke, 1939) associated with exercise, meals, menses, etc., was minimized by collecting all blood samples at the same time of day and menstrual cycle from subjects who had rested half an hour or more and whose last meal had been taken at least four hours previously. Preliminary tests had shown these precautions reduced the variation to $2 \%$.

Wallensten (1954) used as normal haemoglobin levels $15.4 \pm 0.9 \mathrm{~g} . / 100 \mathrm{ml}$. for males and $13.4 \pm 0.9 \mathrm{~g} . / 100 \mathrm{ml}$. for females, so that the criteria for anaemia were levels below $13.6 \mathrm{~g}$. for males and below $11.5 \mathrm{~g}$. for females. Levels before operation or haemorrhage were available in 181 of 192 male patients and agree well apart from the wider scatter of random sampling; $15 \cdot 1 \pm 1.3 \mathrm{~g} . / 100 \mathrm{ml}$. Subsequent experience showed (Fig. 1) that after treatment the haemoglobin levels of females rose to within the range expected for normal males, so that one doubts whether the sex difference is physiological.

Haematocrits were determined on all blood samples, and in general the calculated M.C.H.C. confirmed cases of iron deficiency; however, as 16 patients with a normal M.C.H.C. responded to iron therapy, this index is of limited value as an indicator of the need for treatment with iron.

Serum iron was estimated (King and Wootton, 1956) in duplicate, yielding a technical error of $\pm 5 \mu \mathrm{g} . / 100 \mathrm{ml}$. 


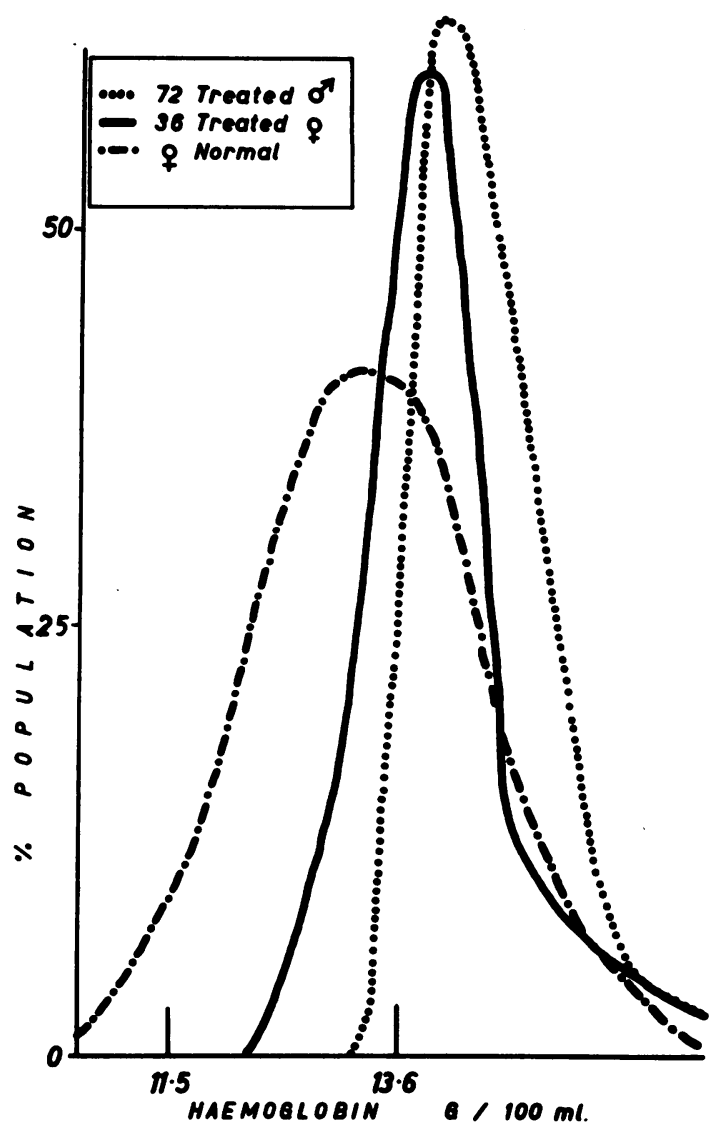

FIG. 1. Frequency distributions of haemoglobin levels of 'normal' females compared with the treated females and males of this consecutive series, suggesting the 'normal' range is not the physiological.
In anaemic patients the results generally confirmed the iron deficiency, though 13 anaemic patients with levels greater than $90 \mu \mathrm{g} . / 100 \mathrm{ml}$. responded to treatment with iron, revealing that serum iron estimations do not indicate precisely the need for such treatment.

Unsaturated serum iron-binding capacity was measured using radioiron (Feinstein, Bethard, and McCarthy, 1953) with a reproducibility of $\pm 15 \mu \mathrm{g} . / 100 \mathrm{ml}$.

After the exclusion of haemorrhoids, occult blood tests on three specimens of fresh stool from each anaemic patient were made using an o-tolidine tube method matching Gregersen's test, which is recognized to become weakly positive with about 0.5 to $3.0 \mathrm{ml}$. of blood loss daily (Hughes Jones, 1958). As false positives are obtained from ingested blood, radishes, etc., each of the six positive patients was carefully dieted and 12 successive stools were tested, when five patients became negative. When true occult blood loss is a cause of anaemia it is not usually so difficult to detect.

Serum $B_{12}$ levels were assayed using $L$. leichmannii and were kindly done by Dr. P. Sewell, then at Kingston General Hospital.

Assessment of factors. Males were classed according to the presence or absence of a factor which might be causing anaemia; from the difference in incidence of anaemia in these two groups the contribution of the factor was calculated (Table II) and tested by the $x^{2}$ method. Although no single factor contributed to a statistically significant degree, most are positive so that an iron balance sheet has been compiled to allow assessment of them additively (Table III).

\section{RESULTS AND DISCUSSION}

THE CASE FOR TREATMENT WITH IRON ALONE In this series anaemia always responded to treatment with some form of iron and no patient needed any other treatment. (All serum $B_{12}$ levels were within normal limits.)

By Wallensten's criteria about half the males and

TABLE II

ANALYSIS OF POSSIBLE AETIOLOGICAL FACTORS OF ANAEMIA IN MEN AFTER PARTIAL GASTRECTOMY

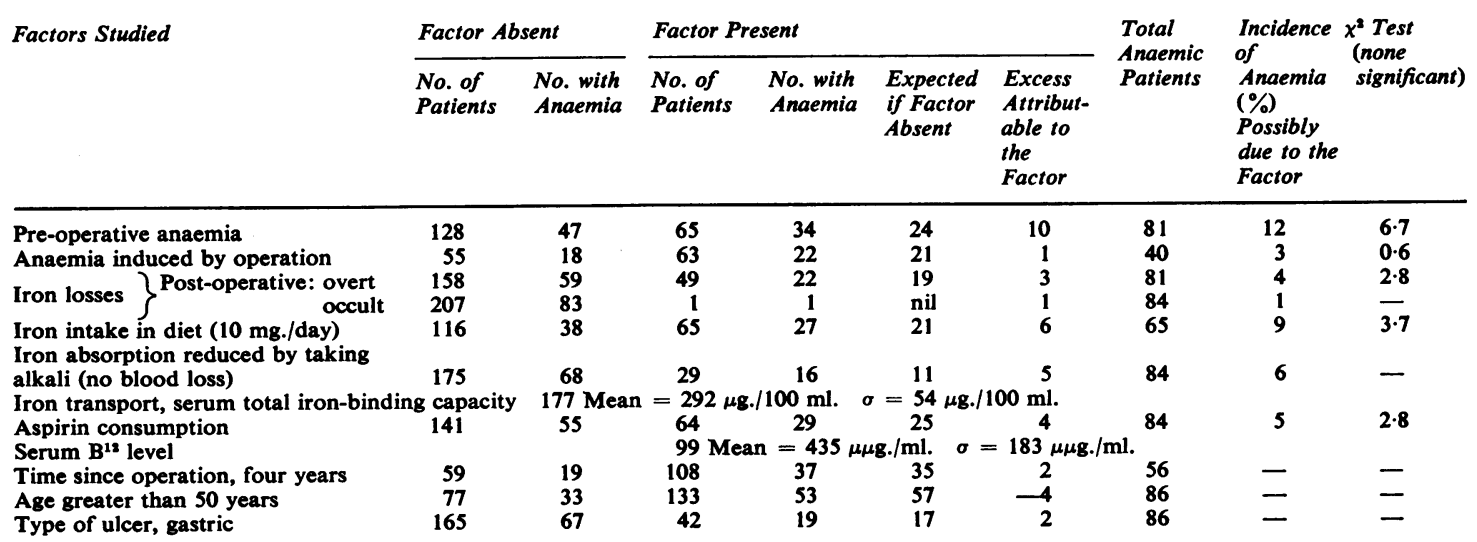


TABLE III

ANAEMIA CAUSED IN 84 MALES AFTER PARTIAL GASTRECTOMY

$\%$ from Table III

\begin{tabular}{llr}
\hline Abnormal iron losses & Pre-operative & 12 \\
& Per-operative & 3 \\
& Post-operative & 5 \\
Abnormal iron intake & Less than $10 \mathrm{mg}$./day & 9 \\
& Aspirin consumption & 5 \\
& Total & 34
\end{tabular}

half the females were anaemic, but if the same standards are applied to females as to males, nearly all the females were anaemic (Table IV). After treat-

\section{TABLE IV}

INCIDENCE OF ANAEMIA AFTER PARTIAL GASTRECTOMY ${ }^{1}$

\begin{tabular}{|c|c|c|c|c|c|}
\hline & \multicolumn{3}{|c|}{ Present Series Alone } & \multicolumn{2}{|c|}{$\begin{array}{l}\text { Present series and serie. } \\
\text { of Watson }(1947), \\
\text { Lyngar (1950), and } \\
\text { Wallensten (1954) }\end{array}$} \\
\hline & $\begin{array}{l}\text { No. of } \\
\text { Patients }\end{array}$ & $\begin{array}{l}\text { No. with } \\
\text { Criterion }\end{array}$ & $\begin{array}{l}\% \\
\text { Anaemia }\end{array}$ & $\begin{array}{l}\text { No. of } \\
\text { Patients }\end{array}$ & $\begin{array}{l}\% \\
\text { Anaemia }\end{array}$ \\
\hline Females & 50 & $\begin{array}{c}\mathrm{Hb}<11.5 \mathrm{~g} \\
21 \\
\mathrm{Hb}<13.6 \mathrm{~g}\end{array}$ & 42 & 227 & 40 \\
\hline $\begin{array}{l}\text { Males } \\
\text { Females }\end{array}$ & $\begin{array}{r}208 \\
50\end{array}$ & $\begin{array}{l}84 \\
48\end{array}$ & $\begin{array}{l}40 \\
96\end{array}$ & $\begin{array}{l}715 \\
207\end{array}$ & $\begin{array}{l}49 \\
94\end{array}$ \\
\hline
\end{tabular}

'This series includes five patients treated for anaemia who are assumed to have had a haemoglobin level below $13.6 \mathrm{~g} . / 100 \mathrm{ml}$.

ment, the haemoglobin levels of both males and females fell within the normal male range except for one man $(13.3 \mathrm{~g}$.) and three women $(12.6,12 \cdot 8$, $13 \cdot 3 \mathrm{~g}$.). The view that iron deficiency was clinically significant is supported by the observation that even when the haemoglobin rise was small, the patient often felt markedly better and 24 of 108 gained weight for the first time since operation. Of the non-anaemic males $23 \%$ had serum iron levels below $60 \mu \mathrm{g} . / 100 \mathrm{ml}$. which was considered to constitute sideropenia (Waldenström, 1946), and the few of these who were treated responded subjectively in the same way as anaemic patients and gained weight. These observations confirm those of Reimann (1956) and Beutler, Larsh, and Gurney (1959) who have shown that sideropenia has a profound effect on energy, muscle mass, and sexual libido, and support those of Ott and Jasinski (1954) who often cured patients of their dumping symptoms by treating the sideropenia which was invariably present.

THE PATHOGENESIS OF THE IRON DEFICIENCY Iron deficiency in all these cases must be due to present or past blood loss, or to an inadequate supply of iron. Women who have not passed the menopause lose 500 to $3,000 \mathrm{ml}$. of blood a year, and of 23 such patients all had a haemoglobin level below $13.6 \mathrm{~g}$., which was exceeded in all cases after treatment. Because of this apparently dominant effect of menstruation, other factors were analysed only in male patients.

Before transfusion became freely available (Morley and Roberts, 1928), survivors from partial gastrectomy for haematemesis were grossly anaemic. Nowadays pre-operative iron loss is less important (Table II) and its contribution can be abolished by adequate transfusion and treatment with iron during convalescence. These same measures minimized the subsequent effects of pre-operative loss, which initially rendered over half the patients anaemic. In the years following operation, overt blood loss, chiefly from haemorrhoids, was of little general significance and individual cases are treated on their own merits. Occult blood loss is rare (Table V) and the speculations of Smith and

TABLE V

OCCULT BLOOD LOSS AFTER PARTIAL GASTRECTOMY

\begin{tabular}{lcc} 
Series & $\begin{array}{c}\text { No. of Patients } \\
\text { Examined }\end{array}$ & $\begin{array}{l}\text { No. of Patients } \\
\text { Found to be } \\
\text { Positive }\end{array}$ \\
\hline $\begin{array}{l}\text { Dedichen (1934) } \\
\text { Hartfall (1934) }\end{array}$ & 47 & 1 \\
Lyngar (1950) & 20 & 1 \\
Blake and Rechnitizer (1953) & 146 & Rarely \\
Baird and Wilson (1959) & 104 & 4 \\
Not anaemic & 32 & 6 \\
$\begin{array}{l}\text { Anaemic } \\
\text { Choudhury and Williams (1959) } \\
\text { Stevens et al. } \text { (1959) Over 1 year } \\
\text { This series }\end{array}$ & 30 & 3 \\
& 40 & 0 \\
& 84 & 0 \\
\end{tabular}

Mallett (1957) are without foundation. There is good evidence against the hypothesis of intermittent loss in that only eight weakly positive occult blood reactions were found in 321 random stools, corresponding to a loss from the average patient of $24 \mathrm{ml}$. of blood in 321 days, whereas the physiological loss over this period is about $90 \mathrm{ml}$. Three cases of acute melaena have been ascribed to aspirin consumption, but if these are excluded only $5 \%$ of the anaemia could have been caused by aspirin. A low dietary iron intake, possibly causing $9 \%$ of the anaemia, was usually due to the eating of small meals as an adaptation to the symptoms of dumping: this constitutes a vicious circle as the dumping symptoms are aggravated by iron deficiency. The age of the patient and the site of the ulcer appear irrelevant.

The factors considered above account for only one third of the anaemia so that the only factor not yet considered, that is, defective iron absorption, must account for the remaining two thirds. 


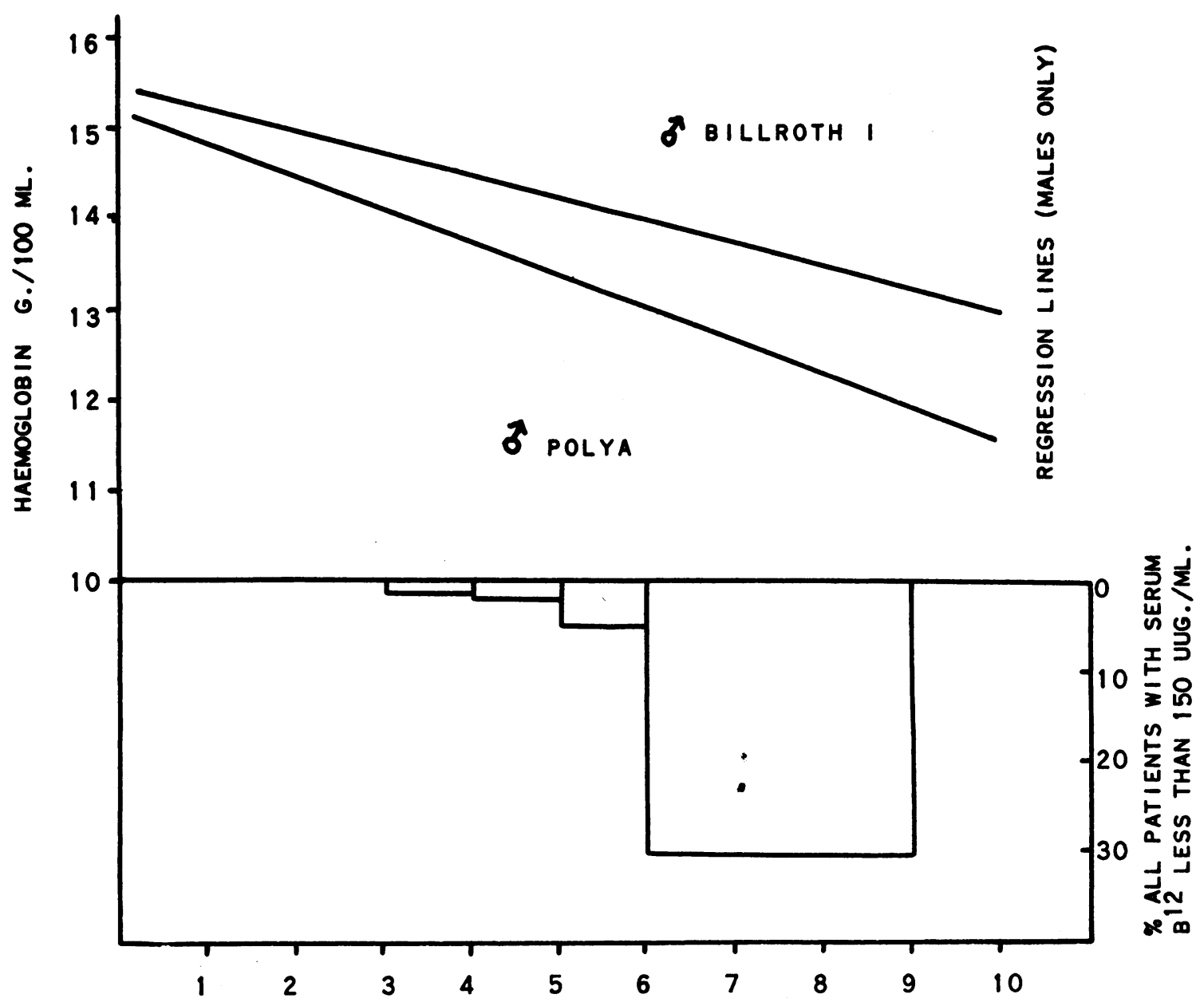

YEARS SINCE OPERATION

FIG. 2. The degree of anaemia (after Baird and Wilson, 1959) and percentage of subnormal serum $B_{12}$ levels (after Sewell) in patients over time after partial gastrectomy.

THE ABSORPTION OF IRON Were iron absorption suddenly to cease, a normal man with $1,000 \mathrm{mg}$. of iron in store and $2,500 \mathrm{mg}$. in haemoglobin $(15 \mathrm{~g}$./ $100 \mathrm{ml}$.) would live for three and a half years before his haemoglobin fell below $13.6 \mathrm{~g} . / 100 \mathrm{ml}$., assuming the reasonable loss of $1 \mathrm{mg}$. of iron daily (Moore, 1955). As most patients were seen more than three and a half years after operation, the criterion of $13.6 \mathrm{~g}$. used in this series and Wallensten's fails to detect an increasing incidence of anaemia with the later years. However, by using a criterion of $12.6 \mathrm{~g}$. (Burge, 1960), or better still, by plotting haemoglobin levels directly against time (Baird and Wilson,
1959), the effect of time since operation is clear (Fig. 2). Sewell (data to be published) has shown that serum $B_{12}$ levels behave similarly (Fig. 2), and their correlation with the iron deficiency suggests that 'sideropenic gastritis' may impair the absorption of $B_{12}$ : since the achylia is initially reversible (Brumfitt, 1960). This hypothesis could explain the spontaneous rise of serum $B_{12}$ levels after iron therapy alone (Cox, Meynell, Gaddie, and Cooke, 1959).

If ferrous ions are presented to any level of the small gut of the cat (Jacobi, Pfleger, and Rummel, 1956) or of man (Holmberg, Vahlquist, and 


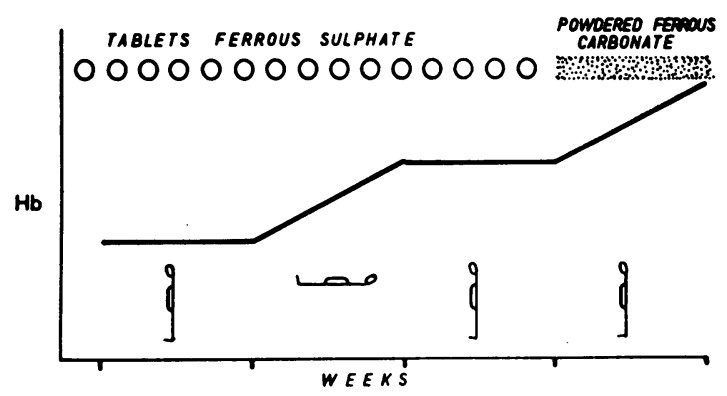

FIG. 3. The influence of posture and disintegration of tablets on iron absorption after partial gastrectomy (after Owren, 1952).

Waldenström, 1944) they are absorbed. In healthy individuals the pancreatic secretion renders the contents of the duodenum neutral or slightly alkaline, so lowering the concentration of ferrous ions that iron is mainly absorbed in the duodenum. It is known that the Polya gastrectomy is followed by more severe anaemia than the Billroth I operation, and Wallensten suggests that this is due to exclusion of the duodenum. Choudhury and Williams (1959) confirmed this difference, but found that patients with gastroenterostomy, in whom the duodenum was no longer a pathway for digesting food, absorbed iron normally. Anaemia only seems to occur when the distal part of the stomach is resected (or excluded, Lublin, 1936), and this area is known to regulate the rate of emptying of the stomach (Thomas, 1957). An alternative hypothesis thus seems to be that failure of absorption is due more to the rapid passage of iron through the upper gut; not only is there less time for ferrous ions to be split off from food (or therapeutic tablets) but they are shorter lived. Radiologically, hurried emptying of the gastric remnant was recorded by Hartfall in 1934, and in 1952 Owren (confirmed by Goldeck and Gadermann, 1954) showed that in the erect posture tablets might reach the terminal ileum within $20 \mathrm{~min}$. and that these patients would only respond when confined to bed, as lying down slowed the transit of the ferrous sulphate tablets so that they disintegrated in the stomach (Fig. 3). Powdered ferrous carbonate in large doses could be effective while patients are ambulant, but Owren admits it is difficult to persuade patients to take this.

These authors alone, among the many who have studied iron absorption after partial gastrectomy (Table VI), have considered the influence of posture and of the physical form in which iron is presented. If ferrous iron in solution is administered to fasting subjects (especially in bed), maximum absorption must occur, yet the presence of food can halve such absorption (Bothwell, Pirzio-Biroli, and Finch, 1958). Consequently such studies reproduce neither the usual conditions of clinical treatment (tablets after meals) nor the natural dietary background against which the iron deficiency develops.

Malabsorption of iron in food has, in fact, been demonstrated after partial gastrectomy (Table VI), and alkali consumption (Table II); achylia per se (Bothwell et al., 1958), jejunitis, and steatorrhoea are of little significance in its causation.

Unsaturated serum iron-binding capacity may be of importance in iron absorption (Hallberg, 1960), and in iron-deficiency anaemia levels above normal (over $300 \mu \mathrm{g} . / 100 \mathrm{ml}$.) are found in association with the known increased ability to absorb iron. The

TABLE VI

RESULTS OF STUDIES OR IRON ABSORPTION AFTER PARTIAL GASTRECTOMY

\begin{tabular}{|c|c|c|c|}
\hline Authors & Method & $\begin{array}{l}\text { No. of } \\
\text { Patients }\end{array}$ & $\begin{array}{l}\text { Evidence for } \\
\text { Malabsorption }\end{array}$ \\
\hline \multicolumn{4}{|l|}{ Using inorganic iron in fasting patients } \\
\hline $\begin{array}{l}\text { Owren (1952) } \\
\text { Goldeck and Gadermann (1954) }\end{array}$ & Radiological & 2 & $\begin{array}{l}\text { Yes } \\
\text { Yes }\end{array}$ \\
\hline $\begin{array}{l}\text { Wallensten (1954) } \\
\text { Heinrich (1954) } \\
\text { Murray et al. (1957) } \\
\text { Zingg et al. (1959) }\end{array}$ & $\begin{array}{l}\text { Plasma iron absorption curves, which can be misleading } \\
\text { (Bothwell et al., 1955) }\end{array}$ & $\begin{array}{c}4 \\
7 \\
2 \\
83\end{array}$ & $\begin{array}{l}\text { Yes } \\
\text { Yes } \\
\text { Yes } \\
\text { No }\end{array}$ \\
\hline $\begin{array}{l}\text { Smith and Mallett (1957) } \\
\text { Baird and Wilson (1959) } \\
\text { Duthie (1959) }\end{array}$ & Radioiron balance & $\begin{array}{r}43 \\
13 \\
4\end{array}$ & $\begin{array}{l}\text { No } \\
\text { No } \\
\text { No }\end{array}$ \\
\hline $\begin{array}{l}\text { Using inorganic iron added to food } \\
\text { Bothwell et al. (1958) } \\
\text { Stevens et al. (1959) }\end{array}$ & Double isotope balance & $\begin{array}{l}5 \\
8\end{array}$ & $\begin{array}{l}\text { Yes } \\
\text { Yes }\end{array}$ \\
\hline Choudhury and Williams (1959) & Radioiron balance & 25 & Yes \\
\hline $\begin{array}{l}\text { Using radioiron incorporated in food } \\
\text { Chodos et al. (1957) } \\
\text { Baird and Wilson (1959) }\end{array}$ & Radioiron balance & $\begin{array}{l}1 \\
4\end{array}$ & $\begin{array}{l}\text { Yes } \\
\text { Yes }\end{array}$ \\
\hline
\end{tabular}


latter could not be demonstrated after partial gastrectomy (Baird and Wilson, 1959), and in 84 anaemic patients no such increase in unsaturated serum iron-binding capacity could be found ( $225 \pm$ $64 \mu \mathrm{g} . / 100 \mathrm{ml}$.): however these results probably reflect the insidious onset of the chronic anaemia, for the described increases (Laurell, 1947) were found in acute cases.

After consideration of the many factors affecting iron absorption after partial gastrectomy it can be said that the most significant cause of the observed malabsorption is an increased rate of emptying of the gastric remnant.

\section{SUMMARY}

An analysis of the literature and a study of 242 patients reveals that, after partial gastrectomy, iron deficiency (1) leads to anaemia in half the males and, because of menstruation, in nearly all the females; (2) apart from causing anaemia, can have far-reaching effects on the other tissues of the body; (3) insidiously develops over the years as a result of the malabsorption of iron from food due chiefly to the rapid emptying of the gastric remnant.

This study has enabled the following principles of management to be defined: (1) Haemoglobin levels should be determined every three months in menstruating women and yearly in other patients. (2) Iron therapy should be given to all patients with a haemoglobin level below $13.6 \mathrm{~g} . / 100 \mathrm{ml}$; continuously, as prophylaxis, to menstruating women; and is worth a trial if sideropenia without anaemia is suspected; in patients complaining of lassitude, failure to maintain weight, or dumping symptoms.

\section{PART II: TREATMENT}

\section{PRINCIPLES}

The case for iron therapy has been stated in Part I of this paper: and parenteral treatment should only be used when there is no alternative.

The object of oral therapy is to present soluble iron to the small gut. Solutions of ferrous salts are unpalatable, are rapidly rendered insoluble by the alkaline contents of the upper small intestine, and are unstable, being readily oxidized to the ferric state with its obnoxious staining and side-effects. They need to be freshly prepared as an elixir and this is expensive and impractical. Tablets, although convenient, would require very rapid dispersal unless taken lying down. Disintegration times in vitro can be misleading as to what actually happens in vivo (Weiner, 1960) but it will be shown that they are of value in iron therapy. Tablets harden with age (Table VII) and a small survey of current iron preparations from the shelves of local pharmacies revealed that, as judged by disintegration times ${ }^{1}$ (Table VII), many of the tablets would be unsuitable for patients after gastrectomy.

\section{TABLE VII}

CONDITION OF IRON TABLETS BEFORE REACHING PATIENTS

Disintegration Time (min.)

\begin{tabular}{llc}
\hline $\begin{array}{l}\text { Ferrous sulphate tablets of a reputable firm } \\
\text { Time since manufacture }\end{array}$ & Fresh & 20 \\
& One month & 30 \\
& Three months & 40 \\
& Six months & 60 \\
& Twelve months & 85 \\
Tablets of various ferrous salts from shelves of & \\
local pharmacies & Range & \\
& Average & $20-140$ \\
& & $40-80$
\end{tabular}

Chelated iron preparations consist of iron combined to an organic complex by $\mathrm{NH}_{2}$ groups in such a way that they are stable in alkaline solutions (Arden, 1950) and are thus available for absorption along the entire small gut. It has been suggested that they by-pass the ferritin mechanism for very high blood levels were achieved rapidly in cats (Jacobi et al., 1956). The ferritin mechanism itself seems to operate by chelating ferrous ions from the gut, so that chelated iron can be loosely regarded as 'predigested'. Of the preparations then available, ferrous glycine sulphate was chosen, being the simplest chelate and also the cheapest. It is not stable in acid solutions, the ferrous moiety becoming ionic at about $p \mathrm{H} 1 \cdot 5$, so that in stomachs with normal acidity it has no advantage over ordinary ferrous salts. However, after partial gastrectomy, it seemed to offer an ideal treatment.

\section{METHODS}

Each patient was given one of four régimes (Table IX) for one month, and then, if the response was bad, the treatment was changed to one of the remaining three and continued until the haemoglobin had risen above 13.6 g. $/ 100 \mathrm{ml}$. (Fig. 4). Only those patients who claimed to have taken over $90 \%$ of the prescribed doses are included in the 214 treatments reported. The criteria of response are arbitrary, taking into account the initial haemoglobin level (Table VIII). The monthly gains may seem small, being about half of what would be expected in patients with intact stomachs, but after partial gastrectomy even parenteral therapy results in a slow response; probably because the $7 \cdot 5 \mathrm{~g}$. of globin, required for each $1 \%(0 \cdot 15 \mathrm{~g}$.) rise, have to come from a protein balance that is critical (Pattarin, 1958).

'Disintegration times were determined by Messrs. Coates \& Cooper Ltd., using the rotating gauze method of the British Pharmacopeia. 
17 MINS. (DISINTEGRATION TIMES) 20 MINS.

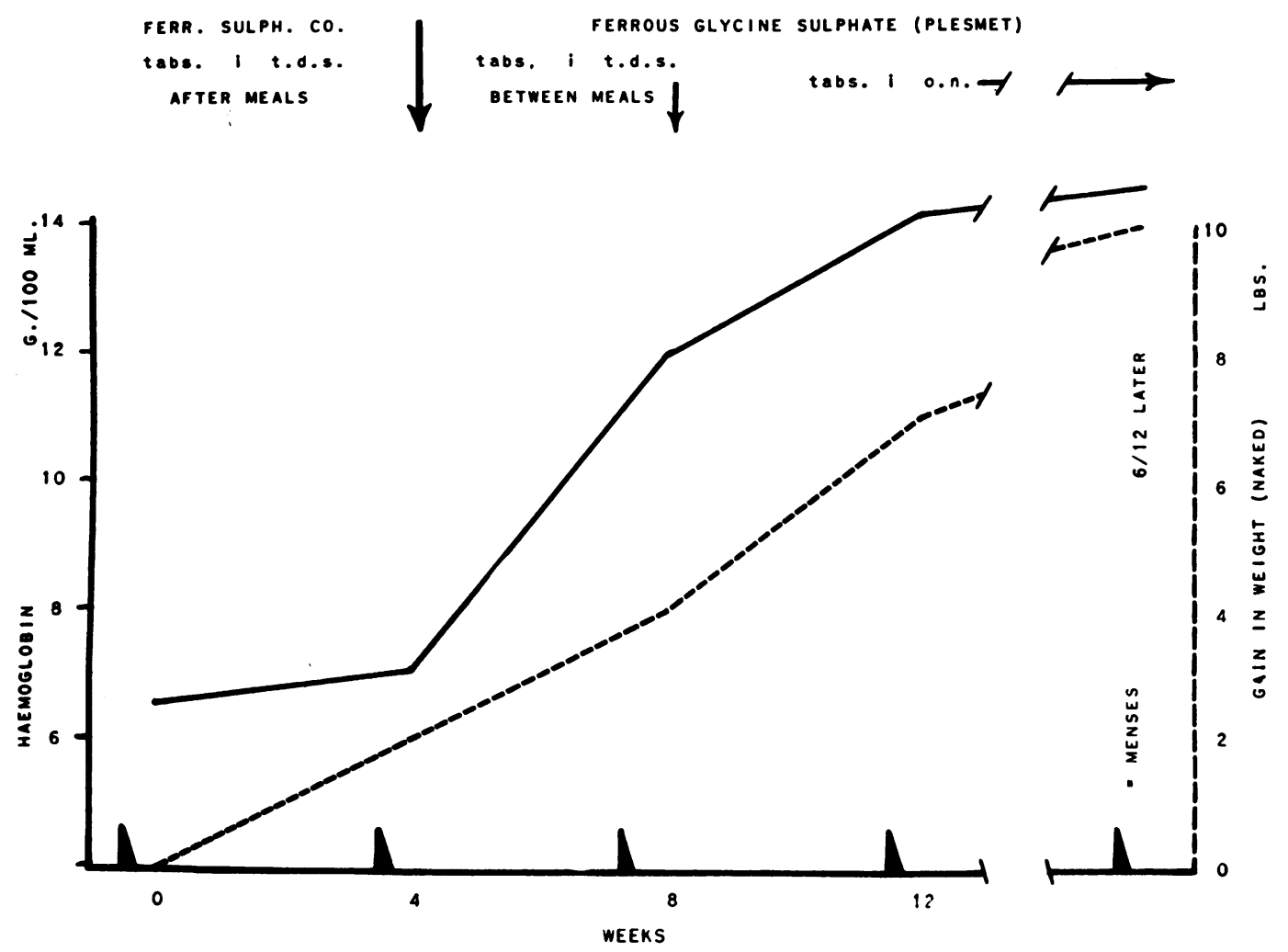

FIG. 4. The treatment of a female patient after the failure of a $6 / 52$ course of ferrous gluconate tablets (ii t.d.s.p.c.). Though all the tablets rapidly disintegrate in vitro, the Plesmet régime was the better and provided adequate maintenance over six months. The weight gain was independent of the haemoglobin response.

\section{TABLE VIII}

CRITERIA OF RESPONSE TO ORAL TREATMENT OF IRONDEFICIENCY ANAEMIA AFTER PARTIAL GASTRECTOMY

\begin{tabular}{|c|c|c|c|}
\hline Initial $H B(\mathrm{~g} . /$ roo $\mathrm{ml})$. & $<9.5$ & $9 \cdot 5 \cdot 11 \cdot 5$ & $>11 \cdot 5$ \\
\hline & \multicolumn{3}{|c|}{ Rise per Month } \\
\hline None & 一 & - & 一 \\
\hline $\begin{array}{l}\text { Unsatisfactory } \\
\text { Satisfactory } \\
\text { Excellent }\end{array}$ & $\begin{array}{l}<1.05 \\
1.05-2.05 \\
>2.05\end{array}$ & $\begin{array}{l}<0.90 \\
0.90-1.65 \\
>1.65\end{array}$ & $\begin{array}{l}>0.60 \\
0.60-0.90 \\
>0.90\end{array}$ \\
\hline
\end{tabular}

RESULTS

The first régime, used routinely in this hospital in the treatment of iron deficiency, is satisfactory for patients with intact stomachs. Table IX shows that after Polya gastrectomy this régime is virtually useless. Even after the Billroth I operation it is not very efficient.
Using treatment, identical except for a more rapid dispersal of the iron tablets, the results after Polya gastrectomy approach those after Billroth I gastrectomy. This supports the hypothesis (Part I) that the rate of emptying of the gastric remnant is more important than duodenal exclusion in the causation of iron malabsorption.

This régime is still inefficient in half the included patients, and as it could not be tolerated by an excluded $20 \%$ of patients, it was not tried between meals.

Ferrous glycine sulphate tablets taken between meals yield excellent results, the more remarkable in that all patients to whom it was given had already failed to respond to ferrous sulphate tablets: further, patients with haemoglobins of 11.5 to $13.6 \mathrm{~g} . / 100$ $\mathrm{ml}$. had taken only one tablet $(50 \mathrm{mg}$. Fe) daily, on lying down at night.

The chelated iron, given as a stable syrup, was 


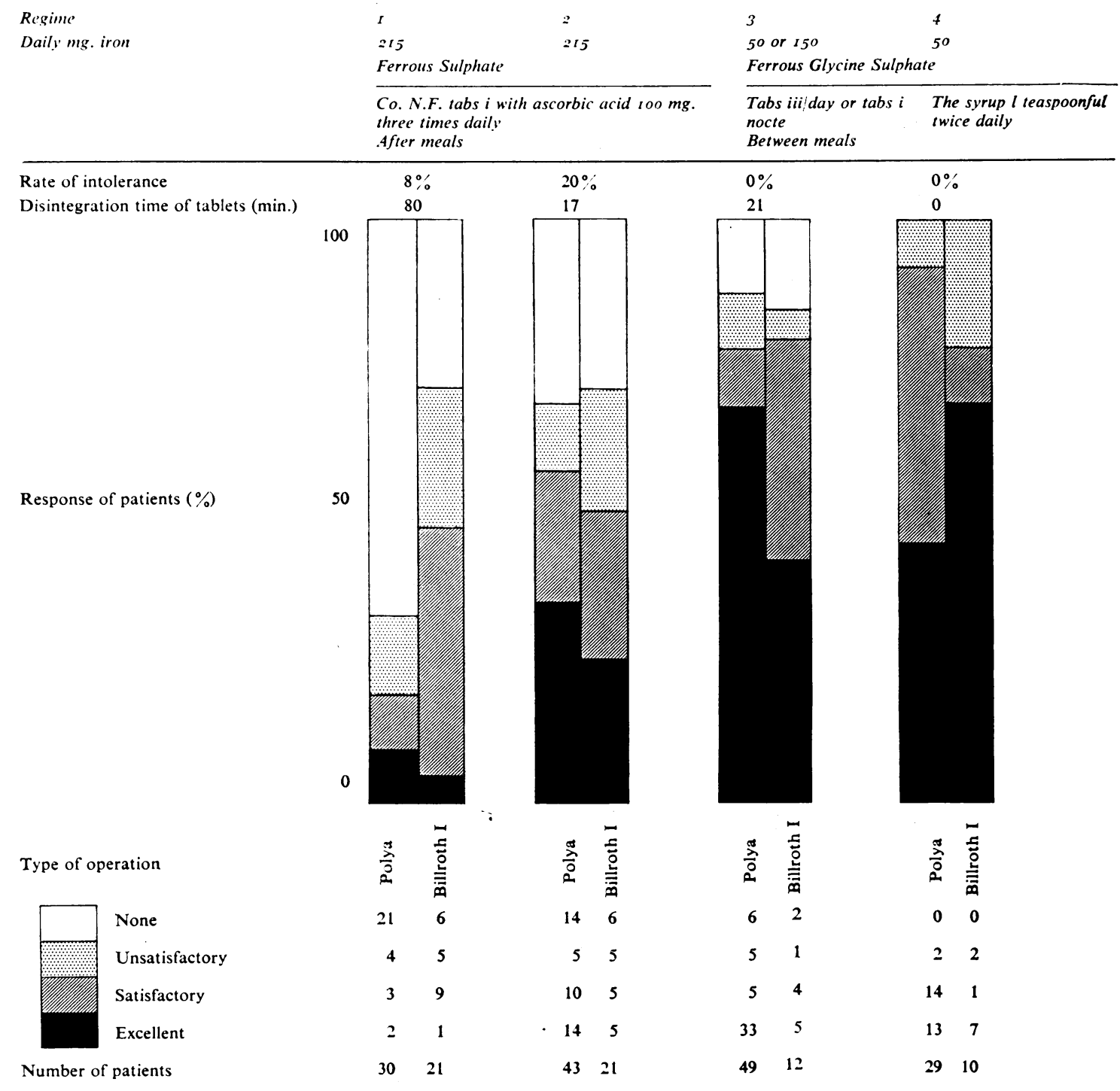

RESULTS OF ORAL IRON THERAPY AFTER PARTIAL GASTRECTOMY

immediately available for absorption. This was satisfactory in the three Billroth $I$ and 11 Polya patients who had failed to respond adequately to all tablets taken by day, when presumably 'hurry' had prevented adequate absorption.

The four patients with unsatisfactory response to the syrup all had haemoglobin levels below 11.5 g. $/ 100 \mathrm{ml}$. Their treatment was changed to ferrous glycine sulphate tablets, one b.d. between meals and one taken on lying down at night. At this higher dosage of $150 \mathrm{mg}$. of iron, they all responded excellently.

\section{DISCUSSION}

When tablets, all with a disintegration time of 30 minutes, are given to ordinary patients in a double-blind trial, no difference in efficacy is 
detected between many of the current ferrous salts, and a genuine intolerance can be shown in $8 \%$ of patients, quite apart from pyschological factors (Berlin, 1960). This coincides with that found in régime 1 ; thus the $20 \%$ rejection of more rapidly distintegrating (17 minutes) ferrous sulphate may be considered as genuine intolerance.

Any attempt to speed up the release of inorganic iron, in an effort to improve absorption, is likely to be rejected by many patients. On the other hand, ferrous glycine sulphate causes minimal side-effects, a finding in agreement with Jennison (1958) and Barnes (1960), presumably because chelation prevents oxidation of the ferrous moiety to obnoxious ferric ions.

It is likely that any tablet, releasing its iron within 30 minutes, will give a satisfactory response if taken lying down. Here, this has only been demonstrated with ferrous glycine sulphate, and one tablet taken last thing every night has been found during the past year to be convenient and adequate in the prevention of a recurrence of anaemia in our menstruating women.

Finally, only the consecutive (unselected) cases from the survey (PartI) are reported here. Experience with some hundred other cases of anaemia after partial gastrectomy supports the findings.

\section{SUMMARY}

The notorious difficulties encountered in the oral treatment of iron deficiency after partial gastrectomy are probably due to an inadequate release of ferrous ions from coated tablets, taken after meals and rapidly emptied from the gastric remnant.

Treatment with tablets of the iron chelate, ferrous glycine sulphate, taken between meals is reliable, though a few patients respond better to the stable syrup.

One tablet, taken on lying down each night, is adequate in the treatment of mild anaemia (haemoglobin 11.5 to $13.6 \mathrm{~g} . / 100 \mathrm{ml}$.) and its prophylaxis in women so long as menstruation continues.

I wish to thank Dr. G. Discombe for his advice and encouragement, Dr. F. Avery Jones and the Department of Gastroenterology for access to their patients, records, and laboratories, Messrs. Coates \& Cooper Ltd. for a supply of ferrous glycine sulphate (Plesmet), our artist and photographic department for help with the diagrams, and those physicians at other hospitals who kindly saw patients who had moved away from this hospital.

\section{REFERENCES}

Arden, T. V. (1950). J. chem. Soc., pp. 882-885.

Baird, I. M., and Wilson, G. M. (1959). Quart. J. Med., 28, 35-41.

Barnes, R. D. S. (1960). Practitioner, 184, 789-792.

Berlin, S-O. (1960)'.

Beutler, E., Larsh, S., and Gurney, C. W. (1959). J. Lab. clin. Med., 54, 791-792.

Blake, J., and Rechnitizer, P. A. (1953). Quart. J. Med., 22, 419-437.

Bothwell, T. H., Mallett, B., Oliver, R., and Smith, M. D. (1955). Brit. J. Haemat., 1, 352-357.

, Pirzio-Biroli, G., and Finch, C. A. (1958). J. Lab. clin. Med., $51,24-36$.

Brumfitt, W. (1960). Quart. J. Med., 29, 1-18.

Burge, H. W. (1960). Postgrad. med. J., 36, 2-12.

Chodos, R. B., Ross, J. F., Apt, L., Pollycove, M., and Halkett, J. A. E. (1957). J. clin. Invest., 36, 314-326.

Choudhury, M. R., and Williams, J. (1959). Clin. Sci., 18, 527-532.

Cox, E. V., Meynell, M. J., Gaddie, R., and Cooke, W. T. (1959). Lancet, 2, 998-1001.

Dedichen, J. (1934). Acta. chir. scand., 75, 242-257.

Duthie, H. L. (1959). Scot. med. J., 4, 523-526.

Feinstein, A. R., Bethard, W. F., and McCarthy, J. D. (1953). J. Lab. clin. Med., 42, 907-914.

Gibson, Q. H., and Harrison, D. C. (1945). Biochem. J., 39, 490-497.

Goldeck, H., and Gadermann, E. (1954). Arztl. Wschr., 9, 39-40.

Hallberg, L. (1960)'

Hartfall, S. J. (1934). Brit. med. J., 1, 136-141.

Heinrich, G. (1954). Arztl. Wschr., 9, 609-611.

Holmberg, C. G., Vahlquist, B., and Waldenström, J. (1944). Om järn och järnterapi. Malmö.

Jacobi, H., Pfleger, K., and Rummel, W. (1956). NaunynSchmiedeberg's Arch. exp. Path. Pharmak., 229, 198-206.

Jennison, R. F. (1958). Practitioner, 181, 731-735.

Jones, N. C. Hughes (1958). Brit. med. J., 1, 493-496.

King, E. J., and Wootton, I. D. P. (1956). Microanalysis in Medical Biochemistry, 3rd ed., p. 108. Churchill, London.

Laurell, C. B. (1947). Acta. physiol. scand., 14, Suppl. 46. p. 82.

Lublin, H. (1936). Amer. J. dig. Dis., 3, 8-10.

Lyngar, E. (1950). Acta med. scand., Suppl. 247.

McCarthy, E. F., and Van Slyke, D. D. (1939). J. biol. Chem., 128, 567-572.

Moore, C. V. (1955). Amer. J. clin. Nutr., 3, 3-10.

Morley, J., and Roberts, W. M. (1928). Brit. J. Surg., 16, 239-252.

Murray, D. H. Jr., Najarian, J. S., Buster, C. D., Scott, K. G., Harper, H. A., and McCorkle, H. J. (1957). Surg. Forum., 8, 211-214.

Ott, W., and Jasinski, B. (1954). Gastroenterologia (Basel), 82, $14-19$. Owren, P. A. (1952). Acta chir. scand., 104, 206-214.

Pattarin, L. (1958). Arch. ital. Mal. App. dig., 24, 187-197.

Reimann, F. (1956). Demonstration at the International Society of Haematology, Boston. (Personal photostats.)

Sewell, P. Personal communication, to be published.

Smith, M. D., and Mallett, B. (1957). Clin. Sci., 16, 23-34.

Stevens, A. R., Piı zio-Biroli, G., Harkins, H. N., Nyhus, L. M., and Finch, C. A. (1959). Ann. Surg., 149, 534-538.

Thomas, J. E. (1957). Physiol Rev., 37, 453-474.

Waldenström, J. (1946). Acta med. scand., Suppl. 170, pp. 252-279. Wallensten, S. (1954). Acta. chir. scand., Suppl. 191.

Watson, A. B. (1947). Brit. J. Surg., 34, 353-366.

Weiner, M. (1960)'

Zingg, W., Green, P. T., Thomas, E. J., and Hamilton, V. (1959). Gastroenterology, 36, 806-811.

${ }^{1}$ To be published in 'The Proceedings of the Seventh European Congress of Haematology'. London, 1959. Karger, Basle (1960). 